\title{
Contribution to the Study of Phytosterols and Phenolics from the Barks and Leaves of the Trichilia catigua A. Juss., Meliaceae
}

\author{
Jessé Boquett Lagos, Carlos Alberto Bruel Gemin, Josiane de Fátima Gaspari Dias, \\ Marilis Dallarmi Miguel, Ranieri Campos, João Luiz de Souza Carvalho, Márcia do Rocio Duarte, \\ Obdulio Gomes Miguel*
}

Programa de Pós-Graduação em Ciências Farmacêuticas, Universidade Federal do Paraná, Curitiba, Brazil.

Email: "obdulio@ufpr.br

Received October $31^{\text {st }}, 2011$; revised November $24^{\text {th }}, 2011$; accepted December $26^{\text {th }}, 2011$

\begin{abstract}
Trichilia catigua is a Brazilian native species known as "catuaba". This study investigated the chromatographic features hydroalcoholic extracts that were obtained by different techniques, from barks and leaves. The chromatographic analysis has demonstrated the presence of chlorogenic acid, epicathechin and cathechin, as well as the presence of $\beta$-sitosterol and stigmasterol in both analyzed plant parts. The best results were those when it was used turbo-extraction, extraction using Soxhlet apparatus and ethanol 50\%.
\end{abstract}

Keywords: Trichilia catigua; Catuaba; Chromatography

\section{Introduction}

The Trichilia catigua A. Juss., Meliaceae barks are very requested as industrial and export raw material. Preclinical studies, with the ethanolic crude extract obtained from the barks of the $T$. catigua, have showed vasorelaxing [1], antinociceptive [2], anti-inflamatory [3] and anti-depressive [4] activities. A mixture of two flavolignanes that were isolated from ethyl acetate portion of $T$. catigua barks has showed antimicrobial activity [5]. NMR and GC-MS of chloroformic portion from T. catigua barks has showed the presence of alkaloids, $\beta$-sitosterol, stigmasterol and campesterol [6]. Cinchonain was isolated from crude hydroalcoholic extract of $T$. catigua barks and a HPLC-UV method was validated for its quantification in commercialized herbal medicines and barks of "catuaba" in Brazil [7]. Botanical studies which in order to accomplish that anatomical characterization of the $T$. catigua bark and leaves were carried out for pharmacognostial purposes [8].

The aim of this study was to compare the performance of five extraction methods of the compounds from $T$. catigua barks and leaves using chromatographic techniques.

\footnotetext{
"Corresponding author.
}

\section{Experimental}

\subsection{Plant Material}

The botanical material was collected in São Miguel do Oeste, with altitude between 522 to 536 meters, latitude $26^{\circ} 46^{\prime} 950^{\prime \prime}$ to $26^{\circ} 47^{\prime} 006^{\prime \prime}$ and longitude $53^{\circ} 30^{\prime} 612^{\prime \prime}$ to $53^{\circ} 30^{\prime} 910^{\prime \prime}$. The samples were dried in a greenhouse at $50^{\circ} \mathrm{C}$ for 24 hours and then grinded in a hammers mill with a $3 \mathrm{~mm}$ sieve. The botanical material was identified by the botanist Dr. Gerdt Hatchbach and a voucher was deposited in Curitiba's botanical garden over the number 306253.

\subsection{Extraction Procedures}

Both of extractions, barks and leaves, were performed with ethanol $96 \%(\mathrm{v} / \mathrm{v})$ and ethanol $50 \%(\mathrm{v} / \mathrm{v})$. It was used $5 \mathrm{~g}$ of dried botanical material in all methods. The final volume was concentrated to $50 \mathrm{~mL}$. The tested were tested: maceration (with $50 \mathrm{~mL}$ of solvent for 24 hours); sonication (with $50 \mathrm{~mL}$ of solvent in ultrasound bath Bransom model 2210 for one hour); turbo extraction (five extractions with $10 \mathrm{~mL}$ of solvent with the Ultra Turrax IKA model T25 basic apparatus at 24,000 rpm for 5 minutes each, after each extraction the solution was centrifuged and the supernatant filtered to a $50 \mathrm{~mL}$ volumetric flask), reflux (with $50 \mathrm{~mL}$ of solvent under reflux 
on a hot plate for one hour) and Soxhlet (with $200 \mathrm{~mL}$ of solvent under reflux hot plate for five hours and then concentrated with a rotary evaporator at $50^{\circ} \mathrm{C}$ to $50 \mathrm{~mL}$ ).

\subsection{GC Analysis}

Analyses were carried out on a Shimadzu 14-B gas chromatograph equipped with a flame ionization detector, with programmable heating ramps and interface CBM101. The data acquisition program used was Class GC. It was used a J \& W Scientific DB-17 fused silica capillary column ( $30 \mathrm{~m} \times 0.53 \mathrm{~mm}, 1 \mu \mathrm{m}$ of film thickness) for the explorative method. Hydrogen was the carrier gas at 30 $\mathrm{kPa}$. The temperature gradient was: initial temperature $100^{\circ} \mathrm{C}$ with $1 \mathrm{~min}$ hold, heating ramp at $7^{\circ} \mathrm{C} / \mathrm{min}$ up to $260^{\circ} \mathrm{C}$ with $66 \mathrm{~min}$ hold. The injector temperature was $260^{\circ} \mathrm{C}$ and the detector temperature was $280^{\circ} \mathrm{C}$. The samples were injected with a split ratio of 1:10 and the injection volume was $4 \mu \mathrm{L}$. It was used a Phenomenex ZB-1 fused silica capillary column $(30 \mathrm{~m} \times 0.53 \mathrm{~mm}, 0.5$ $\mu \mathrm{m}$ of film thickness) for the quantitative method. Hydrogen was the carrier gas at $30 \mathrm{kPa}$. The temperature gradient was: initial temperature $100^{\circ} \mathrm{C}$ with 1 min hold, heating ramp at $8^{\circ} \mathrm{C} / \mathrm{min}$ up to $270^{\circ} \mathrm{C}$ with $35 \mathrm{~min}$ hold and heating ramp at $40^{\circ} \mathrm{C} / \mathrm{min}$ up to $300^{\circ} \mathrm{C}$ with $5 \mathrm{~min}$ hold. The injector temperature was $280^{\circ} \mathrm{C}$ and the detector temperature was $300^{\circ} \mathrm{C}$. The samples were injected in split mode at 1:10 and the injection volume was $4 \mu \mathrm{L}$. The reference standards stigmasterol, $\beta$-sitosterol, lupeol, $\alpha$-amyrine and $\beta$-amyrine and internal standard tocopherol acetate were diluted in ethanol. The samples were prepared adding $25 \mathrm{~mL}$ of the ethanolic crude extract in 5 $\mathrm{mL}$ of distilled water and extracted five times with 20 $\mathrm{mL}$ of petroleum ether with agitation of the solution in vortex. After each extraction the solution was centrifuged and the ethereal portions were gathered and evaporated to dryness at $50^{\circ} \mathrm{C}$. The residue was ressuspended with ethanol, $500 \mu \mathrm{L}$ of internal standard solution at $1 \mathrm{mg} / \mathrm{mL}$ was added, and the extract was transferred in a $5 \mathrm{~mL}$ volumetric flask and brought to volume with ethanol. The solution was centrifuged prior to the injection. The presence of the identified substances was confirmed by the addition of $0.1 \mathrm{mg} \cdot \mathrm{mL}^{-1}$ of the reference standards in the samples of the extracted crude extracts.

\subsection{HPLC Analysis}

Both qualitative and quantitative HPLC analyses were developed in a Merck-Hitachi LaChrom Elite high pressure liquid chromatograph equipped an L-2450 DAD detector, L-2300column oven, L-2130 quaternary pump and L-2200 autosampler. The data acquisition program used was EZChrom Elite. Separations were performed in a Waters X-Terra RP-18 column $(250 \times 4.6 \mathrm{~mm}, 5 \mu \mathrm{m})$ associated to an equivalent pre-column. The column oven operated at $25^{\circ} \mathrm{C}$. The mobile phase was phosphoric acid at $0.2 \%$ in sulfuric acid $0.01 \mathrm{M} \mathrm{(A)}$ and acetonitrile $90 \%$ in purified water (B). The DAD detector operates from 200 to $400 \mathrm{~nm}$ and chromatograms were acquired at 280 $\mathrm{nm}$ for the explorative method and at $326 \mathrm{~nm}$ on the quantitative method. The qualitative method used was: $90 \%$ to $88 \%$ of (A) in $25 \mathrm{~min}, 63 \%$ of (A) in $75 \mathrm{~min}$, $10 \%$ of (A) in $77 \mathrm{~min}$, hold $6 \mathrm{~min}$ and down to initial conditions in $7 \mathrm{~min}$ at a flow rate of $0.7 \mathrm{~mL} / \mathrm{min}$. The quantitative method used was: $80 \%$ to $77 \%$ of (A) in 9 min with a flow rate of, $10 \%$ of (A) in $10 \mathrm{~min}$, hold 4 $\mathrm{min}$ and return to initial conditions in $6 \mathrm{~min}$ at a flow rate of $0.7 \mathrm{~mL} \cdot \mathrm{min}^{-1}$. The standards stock solutions of gallic acid, epicatechin, chrologenic acid, caffeic acid, catechin, coumarin, $p$-coumaric acid, ferulic acid and rutin were prepared in methanol and then diluted with the acidic mobile phase. The barks and leaves crude extracts were diluted four times in the acidic mobile phase for the qualitiative method and 7 times for the quantitative method. The presence of the phenolic compounds was confirmed by the addition of $0.1 \mathrm{mg} \cdot \mathrm{mL}^{-1}$ of standard in the samples in the samples of crude extracts diluted in acidic mobile phase.

\subsection{Statistical Analysis}

All the quantifications were performed in triplicate. Significant differences were statistically evaluated using analysis of variance (one-way ANOVA) and the Tukey test on untransformed data. For all tests, statistical significance was set at $p<0.05$. STATISTICA ${ }^{\circledR}$ software was used for statistical analysis of the data.

\section{Results and Discussion}

A CG method for phytosterols and terpenoids detection was developed with high efficiency in the separation of stigmasterol, $\beta$-sitosterol, lupeol, $\alpha$-amyrine and $\beta$-amyrine. This explorative method was used to obtain the bark and leaves extract crude fingerprint to identify the presence of these substances ethanolic by co-injection with standarts.

The chromatograms have demonstrated the coincidence of peaks, in the same relative retention time for the stigmasterol with RRT of 1.163 in the barks and 1.165 in the leaves. Also the presence of $\beta$-sitosterol was verified by the presence of a peak on 1.262 in the barks and 1.268 in the leaves. Between the samples and the standards confirmation was done with addition of genuine standards to the extracts and it was observed an increase of the corresponding peaks areas without showing new peaks or any kind of peak shape distortion in the chromatogram.

It was observed the presence of $\beta$-sitosterol in a high concentration therefore this compound was the chosen one for quantitative analysis. It was used a more polar chromatographic column (ZB-1) in order to reduce the 
analysis time and it still has efficiently separated $\beta$-sitosterol $(\mathrm{RRT}=1.159)$ from the other extract's substances, in 60 minutes, reducing the time of the analysis and the overall operational costs. The chromatographic extracts profile obtained with the column ZB-1 was very similar to the preview obtained with the DB-17 column. This methodology was validated to be used in the quantification of $\beta$-sitosterol on extractive efficiency tests. The data regarding the validation are showed in Table 1.

The Soxhlet extract with ethanol $50 \%$ has presented the highest quantity of $\beta$-sitosterol for the extraction of both barks and leaves, in a yield of $396 \mu \mathrm{g} / \mathrm{g}$ and 777 $\mu \mathrm{g} / \mathrm{g}$ respectively. On the other hand, the maceration method was the least efficient in the $\beta$-sitosterol extraction with ethanol $50 \%$, where the yield was $37,38 \mu \mathrm{g} / \mathrm{g}$ and $28,29 \mu \mathrm{g} / \mathrm{g}$ on the barks and leaves respectively. All the other extractive methods tested have presented the higher extraction yields with ethanol $96 \%$ as a solvent. It was observed that the second best extractive method was the turbo extraction with ethanol $96 \%$, therefore the solvent renewal in the extractive process helps the extraction of $\beta$-sitosterol, as both Soxhlet and turbo extraction methodologies used solvent renewal in the extractive process (Table 2).

Table 1. Results of GC method validation.

\begin{tabular}{|c|c|c|c|c|c|}
\hline & Analyzed Parameter & \multicolumn{3}{|c|}{ Specification } & Obtained Results \\
\hline \multirow{2}{*}{ Specificity } & RRT correlation with standard peak & Minimum 95\% & B-si & osterol & 97.81 \\
\hline & Resolution versus other peaks & Minimum 1.0 & & & Complies \\
\hline Linearity & Correlation coefficient & \multicolumn{3}{|c|}{$\mathrm{r}^{2} \geq 0.99$} & $r^{2}=0.99832$ \\
\hline \multirow{4}{*}{ Precision } & Method & \multicolumn{3}{|c|}{ Analysis RSD $\leq 5 \%$} & $1.0 \%$ \\
\hline & \multirow{3}{*}{ Intermediate } & \multirow{3}{*}{ Analysts RSD $\leq 5 \%$} & \multicolumn{2}{|c|}{ Analyst 01} & $0.72 \%$ \\
\hline & & & \multicolumn{2}{|c|}{ Analyst 02} & $0.74 \%$ \\
\hline & & & \multicolumn{2}{|c|}{ Analyst 03} & $0.38 \%$ \\
\hline \multirow{3}{*}{ Accuracy } & \multirow{3}{*}{ Addition of standards } & \multirow{3}{*}{ Recovery 95 to $105 \%$} & Concentration 1 & $50 \mu \mathrm{g} / \mathrm{mL}$ & $99.67 \%$ \\
\hline & & & Concentration 2 & $100 \mu \mathrm{g} / \mathrm{mL}$ & $100.23 \%$ \\
\hline & & & Concentration 3 & $150 \mu \mathrm{g} / \mathrm{mL}$ & $100.10 \%$ \\
\hline \multirow{3}{*}{ Robustness } & Carrier gas velocity alteration & \multicolumn{3}{|c|}{$\mathrm{RSD} \leq 5 \%$ respect to standard conditions } & $0.29 \%$ \\
\hline & Column batch change & \multicolumn{3}{|c|}{$\mathrm{RSD} \leq 5 \%$ respect to standard conditions } & $0.22 \%$ \\
\hline & Column oven temperature alteration & \multicolumn{3}{|c|}{$\mathrm{RSD} \leq 5 \%$ respect to standard conditions } & $0.25 \%$ \\
\hline
\end{tabular}

${ }^{*} \mathrm{RSD} \%=$ relative standard deviation.

Table 2. Statistical analysis of the $\beta$-sitosterol and chlorogenic acid content based on different extractive methods.

\begin{tabular}{|c|c|c|c|c|c|c|c|}
\hline $\begin{array}{l}\text { Extraction } \\
\text { method }\end{array}$ & Material and Solvent & $\begin{array}{l}\text { Average content of } \\
\beta \text {-sitosterol }(\mu \mathrm{g} / \mathrm{g})\end{array}$ & $\begin{array}{l}\text { Standard } \\
\text { deviation }\end{array}$ & Variance & $\begin{array}{c}\text { Average content of } \\
\text { chlorogenic acid }(\mu \mathrm{g} / \mathrm{g})\end{array}$ & $\begin{array}{l}\text { Standard } \\
\text { deviation }\end{array}$ & Variance \\
\hline \multirow{4}{*}{ Soxhlet } & Barks EtOH 50\% & $396.31^{\mathrm{a}}$ & 3.803 & 23.066 & $1932.91^{\mathrm{a}}$ & 1.970 & 3.882 \\
\hline & Leaves EtOH 50\% & $777.14^{\mathrm{b}}$ & 1.786 & 3.191 & $1565.77^{\mathrm{b}}$ & 1.782 & 3.175 \\
\hline & Barks EtOH 96\% & $252.33^{\mathrm{c}}$ & 3.940 & 15.526 & $951.24^{\mathrm{c}}$ & 2.061 & 4.248 \\
\hline & Leaves EtOH 96\% & $581.65^{\mathrm{d}}$ & 1.320 & 1.743 & $927.25^{\mathrm{d}}$ & 0.655 & 0.429 \\
\hline \multirow{3}{*}{ Reflux } & Barks EtOH 50\% & $57.44^{\mathrm{e}}$ & 2.194 & 4.814 & $1823.40^{\mathrm{e}}$ & 3.593 & 12.912 \\
\hline & Barks EtOH 96\% & $230.49^{\mathrm{g}}$ & 1.980 & 3.920 & $551.20^{\mathrm{f}}$ & 1.754 & 3.078 \\
\hline & Leaves EtOH 96\% & $399.193^{\mathrm{a}}$ & 2.217 & 4.913 & $534.70^{\mathrm{g}}$ & 2.324 & 5.399 \\
\hline \multirow{4}{*}{ Turbo extraction } & Barks EtOH 50\% & $190.62^{\mathrm{h}}$ & 1.263 & 1.595 & $2046.41^{\mathrm{h}}$ & 1.357 & 1.842 \\
\hline & Leaves EtOH $50 \%$ & $294.70^{\mathrm{i}}$ & 3.081 & 16.654 & $1702.37^{\mathrm{i}}$ & 1.800 & 3.238 \\
\hline & Barks EtOH 96\% & $313.33^{\mathrm{j}}$ & 2.229 & 4.967 & $475.87^{\mathrm{j}}$ & 0.514 & 0.264 \\
\hline & Leaves EtOH 96\% & $534.03^{1}$ & 3.846 & 14.788 & $278.07^{1}$ & 0.250 & 0.063 \\
\hline \multirow{3}{*}{ Maceration } & Leaves EtOH $50 \%$ & $28.29^{n}$ & 1.955 & 3.821 & $1199.14^{\mathrm{n}}$ & 1.881 & 3.539 \\
\hline & Barks EtOH 96\% & $221.58^{\circ}$ & 0.621 & 0.385 & $424.07^{\circ}$ & 1.344 & 1.807 \\
\hline & Leaves EtOH 96\% & $366.11^{\mathrm{p}}$ & 3.699 & 22.084 & $195.40^{\mathrm{p}}$ & 0.406 & 0.164 \\
\hline \multirow{4}{*}{ Sonication } & Barks EtOH 50\% & $51.92^{\mathrm{e}}$ & 0.542 & 0.294 & $1645.22^{q}$ & 2.561 & 6.558 \\
\hline & Leaves EtOH 50\% & $53.32^{\mathrm{e}}$ & 3.419 & 11.692 & $1436.60^{\mathrm{r}}$ & 0.878 & 0.771 \\
\hline & Barks EtOH 96\% & $170.34^{\mathrm{s}}$ & 0.613 & 0.376 & $426.83^{\circ}$ & 1.647 & 2.714 \\
\hline & Leaves EtOH 96\% & $288.74 \mathrm{i}$ & 2.451 & 6.005 & $274.16^{1}$ & 0.774 & 0.600 \\
\hline
\end{tabular}

"Different letters mean different contents at $95 \%$ of significance. 
The temperature influences positively the $\beta$-sitosterol extraction, because the Soxhlet method was more efficient than turbo extraction. The $\beta$-sitosterol is more soluble in ethanol than in water and it justify a better yield with ethanol $96 \%$ when it was compared to ethanol $50 \%$. However, the extraction in Soxhlet with ethanol $50 \%$ has presented a larger yield of $\beta$-sitosterol than the extraction with ethanol $96 \%$. This fact can be explained due the presence of water in the solvent, allied to the heat soften the vegetable material, that facilitate the ethanol penetration into the tissues. These results are in agreement with the literature [9] which demonstrated the superior efficiency of the terpenoid and steroids ethanol's extraction with Soxhlet in tobacco's leaves.

According to statistical analyses, most of the extraction methods and solvent concentrations were different at $5 \%$ of significance, except for the extraction of the barks and leaves with ethanol 50\% reflux and sonication extractions. In the species T. catigua the leaves presented a larger content of $\beta$-sitosterol that the barks in all extractive methods tested (Table 2).

A HPLC-DAD method was developed in order to investigate the presence of phenollic compounds in $T$. $c a$ tigua bark and leaves. An explorative method was used to obtain the chromatographic fingerprint and it was identified the presence of phenolic compounds on extracts. This method was able to efficiently separate the gallic acid, epicathechin, cathechin, chlorogenic acid, cafeic acid, cumarine, p-cumaric acid, ferulic acid and rutin standards.

The crude extracts were injected without the needing of sample preparation. The analysis of the chroma-tograms has demonstrated the coincidence of the retention time of cathechin, chlorogenic acid and epicathechin peaks in both plant parts. The identity of these compounds was con- firmed by the addition of genuine standards in the extracts, and the analysis of the peak purity was accomplished by DAD detector software, which was satisfactory on excluding the co-elution of different substances. The presence of chlorogenic acid was not mentioned in this species yet. The chlorogenic acid was identified as the phenolic compound with the highest concentration on plant parts and a new method for its quantification was developed to reduce the analysis time from 90 down to 20 minutes using the same chromatographic conditions. This methodology was validated to be used in the chlorogenic acid quantification in the extractive efficiency tests. Data regarding the method validation are showed in the Table 3.

According to Table 2, the turbo extraction method with ethanol $50 \%$ presented the highest content of chlorogenic acid on the barks and leaves extract with yields of $2046 \mu \mathrm{g} / \mathrm{g}$ and $1702 \mu \mathrm{g} / \mathrm{g}$ respectively. In agreement with the phytosterols study, the maceration method was the least efficient for the extraction of chlorogenic acid with a content of $1592 \mu \mathrm{g} / \mathrm{g}$ and $1199 \mu \mathrm{g} / \mathrm{g}$ from barks and leaves respectively, approximately $25 \%$ less than the turbo extraction method. The second best extractive method was Soxhlet with ethanol $50 \%$, confirming that solvent renewal in the extractive process is important to the highest yield achievement. The superior efficiency of the turbo extraction can be due to the pulverization of the drug material particles during the extractive process that exposes the internal content of the cells, facilitating the action of the extracting solvent. The presence of water in the solvent again caused the softening of the plant tissue facilitating the ethanol extraction of the components. According to the statistical analyses, most of extraction methods and solvent concentrations tested were different at $95 \%$ of significance level except for: extraction of the leaves with ethanol $50 \%$ on reflux and Soxhlet for chlorogenic

Table 3. Results of HPLC method validation.

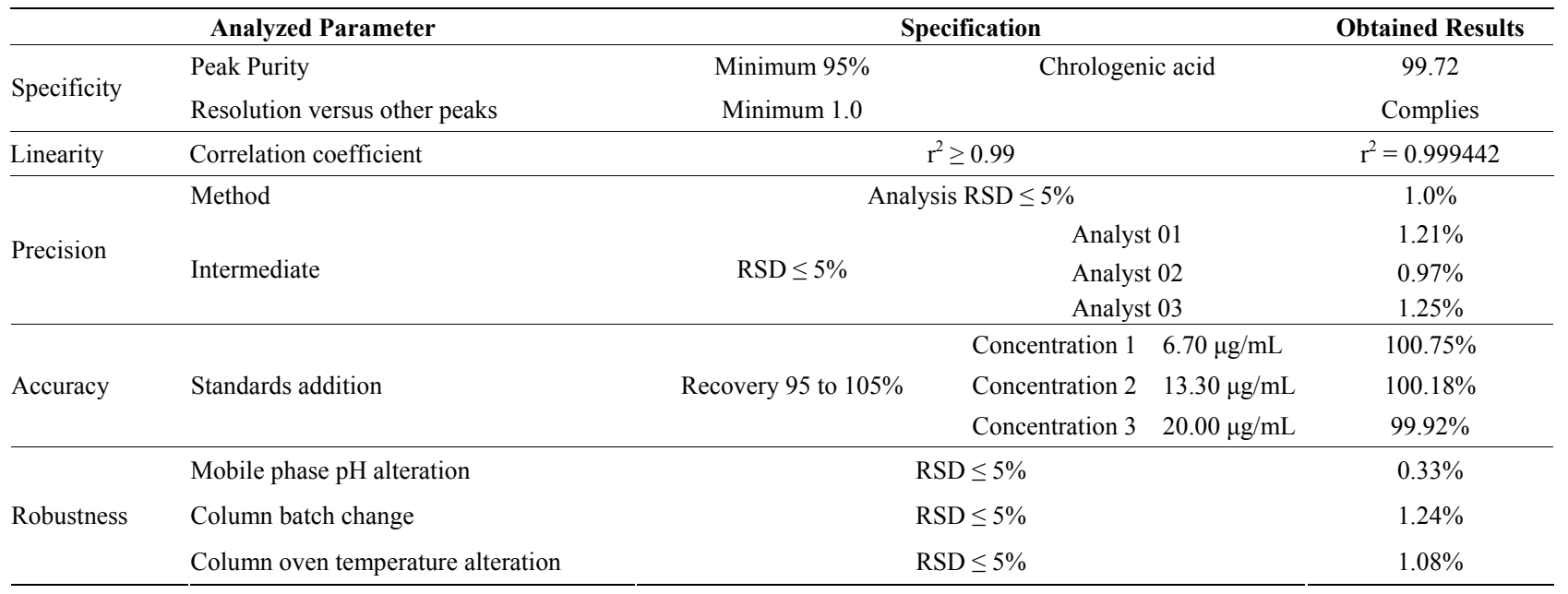

${ }^{*} \mathrm{RSD} \%=$ relative standard deviation. 
acid; extraction of the barks with ethanol $96 \%$ on maceration and sonication for chlorogenic acid; extraction of the leaves with ethanol $50 \%$ on turbo extraction and ethanol $96 \%$ on sonication for $\beta$-sitosterol. The barks presented a higher content of chlorogenic acid that the leaves in all of extractive methods and the leaves presented a higher amount of $\beta$-sitosterol than the barks in all the extractive methods.

\section{Conclusions}

The analytical methodologies developed in this study demonstrated efficiency, safety and reproducibility, being characterized as viable proposals for quality control routines of the species $T$. catigua barks and leaves. The chromatographic analysis demonstrated the presence of chlorogenic acid for the first time in the barks and leaves of the species and confirmed the presence of $\beta$-sitosterol and stigmasterol [6]. All the obtained results of the accomplished analyses are in agreement with the method's validation parameters required by the ANVISA [10]

In the studied conditions it was demonstrated that the best technique for chlorogenic acid extraction is the turbo extraction with ethanol $50 \%$ and for extraction of $\beta$-sitosterol is Soxhlet with ethanol $50 \%$. These results can be useful to future extraction tests for the process in industrial scale. The presented data in this study demonstrated that the T. catigua barks and leaves have a similar chemical composition, which basically differs in the percentage concentrations of the secondary metabolics. Parallel chemical and pharmacological studies could be done to develop a leaves extract that possesses similar pharmacological properties. This fact could reduce the chance of extinction of the species because it could substitute the use of the barks, which actually are collected extensively from native trees. The trees cultivation could be proposed for the production of leaves, facilitating the process of the plant harvest and turning the process ecological [11].

\section{Acknowledgements}

Authors would like to thank to "Laboratório Catarinense SA" for the financial support in the achievement of this study.

\section{REFERENCES}

[1] J. B. Calixto and D. A. Cabrini, "Herbal Catuama Induces Endothelium-Dependent and -Independent Vasorelaxation Action on Isolated Vesselsfrom Rats, Guinea-Pigs and Rabbits," Phytotherapy Research, Vol. 11, No. 1, 1997, pp. 32-38.

doi:10.1002/(SICI)1099-1573(199702)11:1<32::AID-PT

\section{$\underline{\mathrm{R} 33>3.0 . \mathrm{CO} ; 2-\mathrm{C}}$}

[2] R. V. Vaz, L. V. Mata and J. B. Calixto, "Analgesic Effect of the Herbal Medicine Catuama in Thermal and Chemical Models of Nociception in Mice," Phytotherapy Research, Vol. 11, No. 2, 1997, pp. 101-106. doi:10.1002/(SICI)1099-1573(199703)11:2<101::AID-PT $\underline{\mathrm{R} 28>3.0 . \mathrm{CO} ; 2-\mathrm{U}}$

[3] N. R. Barbosa, L. Fischmann, L. L. Talib and W. F. Gattaz, "Inhibition of Platelet Phospholipase A2 Activity by Catuaba Extract Suggests Anti-Inflammatory Properties," Phytotherapy Research, Vol. 18, No. 11, 2004, pp. 942944. doi:10.1002/ptr. 1579

[4] M. M. Campos, E. S. Fernandes, J. Ferreira, A. R. S. Santos and J. B. Calixto, "Antidepressant-Like Effects of Trichilia catigua (Catuaba) Extract: Evidence for Dopaminergic-Mediated Mechanisms," Psypharmacology, Vol. 182 , No. 1,2005 , pp. $45-53$ doi:10.1007/s00213-005-0052-1

[5] M. G. Pizzolatti, A. F. Venson, A. J. Smânia, E. F. A. Smânia and R. B. Filho, "Two Epimeric Flavalignans from Trichilia catigua (Meliaceae) with Antimicrobial Activity," Zeitschrift für Naturforschung, Vol. 57, 2002, pp. $483-488$

[6] M. G. Pizzolatti, L. G. Verdi, I. M. Brighente, L. A. Madureira and R. B. Filho, "Minor Gamma-Lactones from Trichilia catigua (Meliaceae) and Its Precursors by GC-MS," Natural Product Research, Vol. 18, No. 5, 2004, pp. 433-438. doi:10.1080/14786410310001630582

[7] F. L. Beltrame, E. R. Filho, F. A. P. Barros, D. A. Cortez and Q. B. Cass, "A Validated Higher-Performance Liquid Chromatography Method for Quantification of Cinchonain $\mathrm{Ib}$ in Bark and Phytopharmaceuticals of Trichilia catigua Used as Catuaba," Journal of Chromatography A, Vol. 1119, No. 1-2, 2005, pp. 257-263. doi:10.1007/s00216-005-0078-6

[8] J. B. Lagos, "Estudo Comparativo da Composição Química das Folhas e Cascas da Trichilia catigua A. Juss., Meliaceae," Dissertação de Mestrado, Universidade Federal do Paraná, Brazil, 2006.

[9] J. Shen and X. Shao, "A Comparison of Accelerated Solvent Extration, Soxhlet Extraction and Ultrassonic Assisted Extraction for Analysis of Terpenoids and Sterols in Tobacco," Analytical and Bioanalytical Chemistry, Vol. 383, No. 6, 2005, pp. 1003-1009. doi:10.1007/s00216-005-0078-6

[10] ANVISA, “Guia para Validação de Métodos Analíticos e Bioanalíticos," Agência Nacional de Vigilância Sanitária, Resolução RE-899 de 29 de maio de 2003.

[11] J. B. Lagos, M. R. Duarte and O. G. Miguel, "Caracteres Anatômicos de Catuaba (Trichilia catigua A. Juss., Meliaceae)," Acta Farmaceutica Bonaerense, Vol. 26, 2007, pp. 185-190. 